Volume 3 Part 2 April 1973

British

Journal of

Political

Science

Cambridge University Press 


\section{British Journal of Political Science}

Editor: Anthony King, Professor of Government, University of Essex

\section{Editorial Board}

Brian BARRY, Nuffield College, Oxford

B. D. Graham, University of Sussex

Fred. I. Greenstein, Wesleyan University

L. J. Sharpe, Nuffield College, Oxford

DONALD E. Stokes, University of Michigan

Bernard Williams, King's College, Cambridge

Consultative Committee

D. A. Aitkin, Macquarie University, Australia

R. R. ALFORD, University of Wisconsin

J. BLONDEL, University of Essex

I. BUDGe, University of Essex

J. P. CORNFORD, University of Edinburgh

A. Dunsire, University of York

L. A. GunN, University of Glasgow

A. H. Halsey, Nuffield College, Oxford

D. LOCK WOOD, University of Essex

J. Meisel, Queen's University at Kingston, Ontario

G. B. PARRY, University of Manchester

K. Prewitt, University of Chicago

D. W. RAE, Yale University

P. PESONEN, University of Tampere

P. A. REYNOLDS, University of Lancaster

A. Somit, State University of New York at Buffalo

M. J. C. VILE, University of Kent

A. WILDA VSKY, University of California, Berkeley

J. Q. WiLson, Harvard University

S. S. Wolın, University of California, Santa Cruz

M. W. WRIGHT, University of Manchester

EDITORIAL POLICY

The British Journal of Political Science is an independent journal, whose policy is set by its editorial board. It is committed to no methodological orthodoxy over and above the normal canons of scholarship: clear and consistent use of words, logical and mathematical validity, and the use of appropriate evidence to substantiate empirical statements. Contributions are invited in all fields of political science, including political philosophy and political sociology. Work addressed to problems of general significance to students of politics will be published whatever the period(s) or place(s) drawn upon for evidence.

\section{PERMISSIONS}

(C) Cambridge University Press, 1973

For permission to reproduce material from British Journal of Political Science, please apply to the London or New York office of Cambridge University Press.

ISI Tear Service, 325 Chestnut Street, Philadelphia, Pennsylvania 19106, U.S.A. is authorized to supply single copies of separate articles for private use only.

\section{SUBSCRIPTIONS}

British Journal of Political Science is published quarterly in January, April, July and October. The subscription price of a volume (which includes postage) is 16 net in UK (US \$ 19.50 in USA and Canada). Single parts cost $£ 2$ net in UK (US $\$ 6.00$ in USA and Canada) plus postage. Four parts form a volume. Orders may be sent to a bookseller, subscription agent or to the publishers: Cambridge University Press, P.O. Box 92, London NWI 2DB, or in the USA and Canada to Cambridge University Press, 32 East 57th Street, New York, N.Y. I0022. Copies of the journal for subscribers in the USA and Canada are sent by air to New York to arrive with minimum delay. Second class postage paid at New York, N.Y. 


\title{
Democratic Theory
}

\author{
Essays in Retrieval
}

\section{B. MACPHERSON}

The ideas advanced in Professor Macpherson's The Political Theory of Possessive Individualism and The Real World of Democracy are here carried further, made more precise, and applied specifically to future problems of democracy. Neglected problems of democratic theory are examined, as are shortcomings of some current liberal-democratic theories. There is also a new essay on the author's controversy with Peter Laslett about the nature of seventeenth-century English society. $£ 2.75$ paper covers $£$ I.25

\section{The Aberystwyth Papers}

\section{International Politics I9r9-1969}

\section{Edited by BRIAN PORTER}

This book is a distinguished collection of papers by fourteen leading international scholars. They were written in honour of the fiftieth anniversary of the founding of the world's first Chair of International Politics, at the University College of Wales, Aberystwyth. Among the contributors are Hans Morgenthau, Michael Howard, Barbara Ward, and Sir Herbert Butterfield. Es.50

\section{Legal Control of Government}

\section{Administrative Law in Britain and the United States}

\author{
BERNARD SCHWARTZ and H. W. R. WADE
}

The rule of law is a primary article of faith in the British and American democracies. What it means in practice is determined by the rules of administrative law, which set numerous legal limits to the powers of government. This work compares the systems of the two countries, both in general and in detail. $£_{3}$

\section{The Migration of Workers}

\section{in the United Kingdom and the European Community}

\section{W. R. BÖHNING}

Freedom of movement for workers is a fundamental tenet of the European Economic Community. This book analyses the experience of the Six, and of Britain and Switzerland; the likely size, composition, and direction of future cross-Channel migration are shown to run counter to popular expectation. 29 tables $£ 3$ Institute of Race Relations

OXFORD UNIVERSITY PRESS 


\section{FOUR NEW PELICAN INTRODUCTORY TEXTS IN POLITICAL SCIENCE}

Government and political systems Opposition Past and Present of a Political Institution

Ghita lonescu and Isabel de Madariaga A survey of the development, the present role and the future possibilities of opposition, vital to the functioning of the parliamentary system. $40 p$

International relations

International Politics

Conflict and Harmony

Joseph Frankel

The author surveys the whole field of international. politics, and analyses the alternate modes of conflict and co-operation which he discerns in all the aspects of its structure and process. 50p

American government

Politics in the U.S.A.

Professor M J C Vile

A comprehensive account of the nature and workings of the American political system, in which Professor Vile discusess such characteristics as the two-party system and the functions of the various branches of government. The final chapter is devoted to a survey of the contemporary political scene in America. 50p

American government and political sociology The Agony of the American Left Christopher Lasch

The essays in this book deal with the beginnings of the mass-based American radical movements in the early part of this century, the reasons for their failure and the consequences. 50p

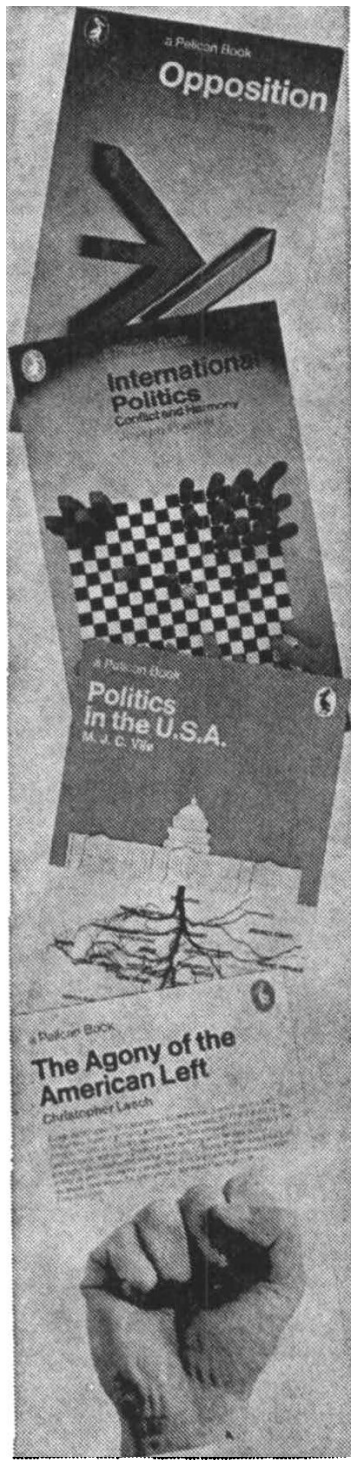

See these titles at your local bookshop. For further information please write to Penguin Education, P.O. Box 11, Bath Road, West Drayton, Middlesex, UB7 ODA. 


\section{SPOTLIGHT ON ASIA Five New Pelican Titles For Spring 1973}

My War with the CIA: Cambodia's Fight for Survival by Norodom Sihanouk, as related to Wilfred Burchett Prince Sihanouk's personal account of the whole story, from his first meetings with John Foster Dulles, heading the U.S. State Department and Allen Dulles, directing the CIA, to the coup d'état of 18 March 1970.

$50 \mathrm{p}$ in UK

Japanese Imperialism Today: Co-prosperity in Greater Asia by Jon Halliday and Gavan McCormack

An account of Japan's transition from a defeated empire to a new world-wide economic and political power, dominating the markets and politics of much of Asia.

Publication May

China: The Revolution Continued by Jan Myrdal

Jan Myrdal's follow up to his Report from a Chinese Village, ten years on.

Publication March

China Shakes the World by Jack Belden

The classic account of the Chinese Civil War.

Publication February $75 p$ in UK

The Chinese Road to Socialism

by $E$ L Wheelright and Bruce McFarlane

An essay on the role of ideology and of the human factor in Chinese economic development.

Publication June

Look for these titles at your local bookshop. Further information concerning Pelican titles may also be obtained by writing to Penguin Education, Harmondsworth, Middlesex. 


\section{Sixth Essex Summer School in Social Science Data Analysis}

\section{July to 19 August 1973}

The European Consortium for Political Research will be sponsoring the Sixth School, to be held at Essex from 9th July to Igth August. The main subjects to be covered will be selected from a range including:

\section{Elements of Data-analysis and Computer Programming Mathematical Theory of Regression \\ Topics in Advanced Regression Analysis \\ Scaling and Data Theory \\ Multi-dimensional Analysis-Metric and Non-metric \\ Critique of Causal Modelling \\ Time Series Analysis \\ Matrix Algebra and Calculus \\ Mathematical Political Theory \\ Computer-based Simulation \\ Problems of Cross-national Aggregate Analysis \\ Problems of Survey-based Analysis of Cross-national Voting Behaviour}

Instruction will emphasize particularly the application of these techniques to data collections held by the School. Full supporting computer facilities will be available. This year there will be a concurrentj summer school in quantitative methods for historians. There will be ample opportunities for mixing between the two schools, and for exchanges of ideas and criticisms. Financial support may be available to participants from their own Institutions or National Research. Councils; failing such support, the Consortium may offer aid to suitable applicants: The organizers particularly wish to attract graduate students, research assistants and junior staff. Interested persons should write to:

The Organizing Secretary

Sixth Essex Summer School

Department of Government

University of Essex, Colchester $\mathrm{CO}_{4} 3 \mathrm{SQ}$, England 